Syntax Literate : Jurnal Ilmiah Indonesia p-ISSN: 2541-0849

e-ISSN : 2548-1398

Vol. 4, No. 9 September 2019

\title{
PENERAPAN PEMBELAAN HAK KEPEMILIKAN TANAH OLEH LBH SGJI DI DESA SUKAJADI KECAMATAN CIBALIUNG KABUPATEN PANDEGLANG
}

\section{Mustamid}

Akademi Manajemen Informatika dan Komputer Bumi Nusantara (AMIK BN)

Email: mustamidamspdshmh@gmail.com

\begin{abstract}
Abstrak
Tujuan dari penelitian ini yaitu Pengimplementasian nilai keadilan sosial bagi seluruh rakyat indonesia di masyarakat Desa Sukajadi dengan dilakukannya pembelaaan hukum terhadap hak kepemilikan tanah yang telah dikuasai oleh pemerintah daerah Pandeglang oleh LBH SGJ Indonesia dan mencari solusi pemecahan masalah, dalam penelitian ini permasalahan yang akan dibahas yaitu Apakah kepemilikan tanah oleh masyarakat sudah mendapatkan keadilan dari Negara?, bagaimana negara dapat menjamin kepemilikan tanah masyarakat agar tidak dirampas pihak lain ?, Strategi apa yang diberikan Negara dalam melindungi tanah masyarakat?, apa kendala yang terjadi dalam penegakkan keadilan terhadap kepemilikan tanah adat/hak milik ?. Metode Penelitian yang digunakan Penelitian ini Deskriptif kualitatif, yaitu penelitian yang digunakan untuk memahami fenomena mengenai apa yang dialami subjek penelitian. Tehnik pengambilan subyek menggunakan purposive sampling, pengumpulan data menggunakan observasi, wawancara dan dokumentasi, analisis data menggunakan model interaktif melalui pengumpulan data, reduksi data, penyajian dan penarikan kesimpulan. Hasil penelitian menunjukan bahwa : 1) pengimplementasian sila ke-5 di masyarakat Desa Sukajadi dapat dilakukan dengan melakukan klarifikasi dan komfirmasi kepada pemerintah kabupaten pandeglang melalui LBH SGJ Indonesia 2) Kendala yang dialami, yaitu pertama pemerintah desa tidak memberikan pelayanan maksimal kepada masyarakat (terkesan menutup-nutupi), kedua pemerintah desa tidak mendukung masyarakat yang menuntut hak atas kepemilikan tanah, 3) solusi yang diberikan yaitu Pemerintah kabupaten pandeglang harus mengembalikan hak kepemilikan tanah/ membeli tanah milik masyarakat dan meberikan tindakan hukum atau sangsi hukum kepada pihak-pihak yang melakukan penyerobotan/perampasan tanah.
\end{abstract}

Kata kunci : Implementasi , Pancasila dan hak kepemilikan

\section{Pendahuluan}

Indonesia sebagai negara maritim, Indonesia juga harus memiliki kedaulatan di depan negara lain sebagai bentuk pengakuan atas keberadaan dan kepemilikan sumber daya yang dimiliki (Simarmata, 2017). Pengembangan sikap adil terhadap sesama manusia, kesamaan kedudukan terhadap hukum dan HAM, keseimbangan antara hak dan kewajiban merupakan sikap yang tercermin dari pengamalan nilai Pancasila yakni sila ke-5 yang berbunyi “Keadilan Sosial bagi Seluruh Rakyat Indonesia”. Fungsi dari 
nilai yang terkandung dalam Pancasila sila ke-5 ini berfungsi sebagai tujuan negara. Kebanyakan orang percaya bahwa ketidak adilan harus dilawan dan dihukum, banyak gerakan Sosial dan Politis diseluruh dunia yang berjuang menegakkan keadilan. Tapi, banyaknya jumlah dan variasi teori keadilan memberikan pemikiran bahwa tidak jelas apa yang dituntut dari keadilan dan realita ketidak adilan, tapi faktor ekonomi juga sangat mempengaruhi langkah untuk penegakan keadilan. Masyarakat dengan ekonomi yang kurang tidak bisa menuntut hak nya yaitu kepemilikan tanah yang sudah sekian tahun dirampas haknya, Sejak dahulu tanah memiliki daya tarik tersendiri dan selalu berkaitan dengan kekuasaan. Seorang bangsawan dikatakan kaya jika dia memiliki sejumlah tanah yang luas. Tanah menjadi target penguasaan sebuah resim atau dinasti yang berkuasa, perang selalu berakhir dengan hasil yang mengakibatkan pihak kalah memberikan tanah mereka kepada pihak yang menang. seperti yang terjadi pada masyarakat Desa Sukajadi Kecamatan Cibaliung Kabupaten Pandeglang, tanah milik leluhurnya dikuasai oleh Pemerintah daerah dengan dibangunnya pasar Cibaliung di atas tanah tersebut, akhirnya ahli waris minta bantuan kepada Lembaga Bantuan Hukum dan Hak Asasi Manusia Sunan Gunung Jati Indonesia untuk mengurus masalah kepemilikan tanah tersebut.

Lembaga Bantuan Hukum Sunan Gunung Jati Indonesia dibentuk dan didirikan atas dasar ingin mengimplementasikan dan mewujudkan dari Pasal 1 Ayat (3) Undang-undang Dasar Tahun 1945 menegaskan bahwa "Negara Indonesia adalah Negara Hukum" Pasal 4 Ayat (1), (2) dan (3) Undang-undang Republik Indonesia Nomor : 16 Tahun 2011 Tentang Bantuan Hukum. Pemberian bantuan hukum disini meliputi menjalankan kuasa, mendampingi, mewakili, membela, dan atau melakukan tindakan hukum lain untuk kepentingan hukum penerima bantuan hukum. Bantuan hukum dimaksud adalah meliputi masalah hukum keperdataan, pidana, dam tata usaha negara baik litigasi maupun nonlitigasi (Nomor, 16AD). Dengan kata lain bertujuan membantu masyarakat yang tidak mampu secara ekonomi maupun kedudukan strata sosial di bawah. Selain itu terdorong karena keinginan dalam penegakkan keadilan dan kedudukan yang sama di depan hukum. Jika kita lihat memang dalam berbagai contoh kasus sering kali hukum tumpul keatas akan tetapi sangat tajam ke bawah, disinilah Lembaga Bantuan Hukum Sunan Gunung Jati Indonesia tampil dalam membantu masyarakat menengah ke bawah dalam proses hukum. 
Berdasarkan uraian di atas dapat disimpulakan bahwa tujuan negara Indonesia adalah menjadikan bangsa yang merdeka, bersatu, berdaulat, adil dan makmur. Menjelaskan bahwa nilai Keadilan Sosial bagi seluruh rakyat Indonesia mengandung makna sebagai dasar sekaligus tujuan, yaitu tercapainya masyarakat Indonesia yang adil dan makmur secara lahiriah maupun batiniah. Keadilan sosial bagi seluruh rakyat Indonesia berhak mendapatkan keadilan diantaranya baik dalam bidang hukum, ekonomi, politik dan kebudayaan sehingga terciptanya masyarakat yang adil dan makmur.

Nilai keadilan di Indonesia sudah mulai berkurang atau luntur, hal ini dibuktikan dengan adanya konflik tentang keadilan yang terjadi di Desa Sukajadi Kecamatan Cibaliung Kabupaten Pandeglang. Untuk itu, penulis sangat tertarik untuk melakukan penelitian tentang nilai keadilan dalam penerapan pembelaan hak kepemilikan tanah milik adat yang didampingi oleh LBH SGJ Indonesia selaku kuasa hukumnya, maka peneliti mengambil Judul “Implementasi Sila ke Lima Pancasila Dalam Penerapan Pembelaan Hak Kepemilikan Tanah oleh LBH \& HAM SGJI Di Desa Sukajadi Kecamatan Cibaliung Kabupaten Pandeglang “

\section{Metode Penelitian}

Seluruh rangkaian penelitian ini dilaksanakan berdasarkan jenis penelitian kualitatif melalui pendekatan deskriptif. Pengertian jenis penelitian kualitatif adalah prosedur penelitian yang menghasilkan data deskriptif berupa kata-kata tertulis atau lisan dari orang-orang dan perilaku yang dapat diamati (Lexy, 2002). Penelitian ini dilakukan di Desa Sukajadi Kecamatan Cibaliung Kabupaten Pandeglang, dilaksanakan pada bulan Agustus sampai dengan bulan Desember 2018. Subyek penelitian yaitu individu, benda atau organisme yang dijadikan sumber informasi yang dibutuhkan dalam pengumpulan data (Arikunto, 2010).

\section{Hasil dan Pembahasan}

Selain melakukan observasi terhadap subyek yang diteliti, peneliti juga melakukan pengumpulan data-data maupun surat-surat yang ada hubungannya dengan obyek yang sedang diteliti, termasuk melakukan wawancara untuk mendapatkan informasi mengenai permasalahan tanah adat yang belum terselesaikan dengan baik. 
Berdasarkan hasil wawancara dengan 1 orang ahli waris, 2 orang kepala desa Desa Cibaliung dan Desa Sukajadi dapat di deskripsikan sebagai berikut. Bahwa tanah milik Almarhum Bapak Kaladin dan Almarhumah Ibu Armiah yang telah dibangun Pasar Cibaliung secara sepihak tanpa prosedur hukum yang benar, maka dalam hal ini selaku Ahli warisnya Bapak Karmali dan Bapak Lali menuntut agar tanah tersebut dikembalikan pada ahli warisnya. Untuk memperjuangkan agar apa yang menjadi haknya dikembalikan, maka ahli waris Bapak Karmali meminta bantuan hukum kepada Lembaga Bantuan Hukum (LBH) Sunan Gunung Jati Indonesia yang menjadi kuasa hukumnya. Tanah tersebut sudah bertahun-tahun dan turun-temurun menjadi miliknya dengan bukti rincikan Desa Cibaliung Nomor : 262 perail C 53 seluas 5.500 meter pada SPPT atas nama Bapak Karmali selaku ahli waris dari Bapak Almarhum Kaladin, sedang Persil 53 d seluas 3700 meter dalam SPPT atas nama Bapak Lali, anehnya pada peta bidang persil tersebut tidak dimunculkan dalam gambar, hal ini sudah sangat jelas ada indikasi ketidak wajaran dan ada oknum yang bermain untuk mencari keuntungan secara pribadi secara melawan hukum dan telah mendholimi Bapak Karmali selaku ahli waris dan pemilik tanah yang sah. Indikasi ini benar-benar terstruktur, masif dan sistematis tidak menutupkan kemungkinan melibatkan pejabat yang ada di Pemerintahan Kabupaten Pandeglang dan mungkin juga ada oknum pada Badan Pertanahan Nasional Kabupaten Pandeglang, juga oknum setempat pemerintahan desa.

Yang menjadi keawaman para ahli waris dan ketidak mengertiannya, karena tidak sekolah sehingga tidak terpikirkan untuk membuat Sertifikat atas tanah tersebut. Bila ditanyakan kepada ahli waris jelas tidak mempunyai Sertifikat, hanya bukti rinncikan di Desa Cibaliung Kecamatan Cibaliung Kabupaten Pandeglang Provinsi Banten yang dikeluarkan dan ditanda tangani oleh Kepala Desa Cibaliung Ahmad Huzaeni tanggal 30 Nopember 2018 Nomor : 177/Ds-2012/XI/2018 tidak berubah masih atas nama Almarhum Bapak Kaladin dan Almarhumah Ibu Armiah yaitu bapak kandung dan ibu kandung bapak Karmali dan bapak Lali, begitu juga Surat Pemberitahuan Pajak Terhitung yang dikeluarkan oleh Kantor Pelayanan Pajak Pratama Kabupaten Pandeglang Nomor Obyek Pajak :36.01.030.011.000-1034.7 atas Karmali dan SPPT NOP 36.01.030.011.000.0614.7 atas nama Lali, yang bersangkutan bertahuntahun membayar pajaknya namun tiba-tiba pada tahun 2008 SPPT tersebut tidak dimunculkan kembali tanpa pemberitahuan yang jelas. Melihat adanya seperti ini ahli 
waris mencoba meminta penjelasan kepada pemerintahan desa setempat namun tidak ada hasil yang diharapkan, ahli waris merasa kebingungan harus meminta penjelasan pada siapa lagi, dengan rasa kekecewaan dan kekesalan itu yang didapatkan. Disinilah peran pemerintahan desa harus hadir untuk memberikan pelayanan kepada masyarakat secara terbuka dan profesional sehingga masyarakat merasa puas dan merasakan kehadiran pemerintah desa di saat mayarakat membutuhkannya dan pemerintahan desa adalah abdi masyarakat dan abdi negara harus bisa memberikan pelayanan secara maksimal dan profesional. Dengan sikap pemerintahan desa yang kurang responsip terhadap keluhan masyarakat dalam mencari keadilan terkait tanahnya yang telah dirampas secara sepihak.

Apabila kita kaitkan dengan pengamalan pada sila ke 5 Pancasila “ Keadilan Sosial bagi seluruh rakyat Indonesia" sangat diperlukan kehadiran pemerintah baik dari pemerintahan terendah yaitu pemerintahan desa sampai daerah yang dipimpin oleh seorang Bupati dan pemerintahan Pusat Presiden. Pastilah rakyat akan merasakan kemerdekaan yang sebenarnya rasa adil dan makmur dapart dirasakan.

Sebagai seorang kepala desa sejak menjabat hendaknya menanggalkan segala kepentingan yang bersifat pribadi mengedepankan kepentingan rakyatnya, karena Kepala desa bisa menjabat sebagai Kepala desa karena dipilih oleh rakyatnya, maka berkewajiban sebagai pemegang amanat harus memberikan pelayanannya secara maksimal pada rakyatnya.

Berdasarkan data yang dianalisis dari hasil observasi dan wawancara Pembahasan Pengamalan nilai Pancasila sila ke- 5 (Keadilan sosial bagi seluruh rakyat indonesia) sebagai berikut:

Implementasi nilai-nilai Pancasila sila ke-5 berdasarkan respon dari hasil wawancara denga ahli waris dan kepala desa yaitu ahli waris telah memberi kuasa kepada Lembaga Bantuan Hukum (LBH) Sunan Gunung Jati Indonesia untuk menuntut haknya, sesuai dengan visi dan misi (4) LBH Sunan Gunung Jati Indonesia.

VISI : "LBH SUNAN GUNUNG JATI adalah Lembaga Bantuan Hukum yang didirikan untuk memberikan manfaat untuk semua warga negara tanpa membedakan latar belakang dan golongan. Baik suku, bahasa dan agama diutamakan mengedepankan nilai-nilai Religius, Bermartabat, Berkualitas, Profesionalime dan Mandiri dan senantiasa mengakkan keadilan dan kebenaran yang hakiki”. 
Kalau dikaitkan dengan sila ke- 5 yaitu bahwa seluruh warga negara indonesia berhak mendapatkan keadilan tanpa membedakan golongan ,dengan melakukan pembelaan terhadap keluarga ahli waris untuk memperoleh hak atas tanah yg dimilikinya yang selama ini telah dikuasai oleh pihak lain.

MISI : "Menegakkan Supremasi Hukum (Law Enforcement), perlakuan yang sama atas diri setiap orang di muka hukum dengan tidak mengadakan pembedaan perlakuan (Equality before the Law) " dan Azas Praduga tidak bersalah (Presumption of innocence). Membrikan jasa hukum baik di dalam Pengadilan maupun diluar pengadilan yang meliputi memberikan konsultasi hukum, bantuan hukum, menjalankan kuasa, mewakili, mendampingi, membela, dan melakukan tindakan lain untuk kepentingan klien".

Implementasi dari sila ke- 5 yaitu : Di sini keadilan harus ditegakan dan adanya pembelaan terhadap hak-haknya, memberikan tindakan hukum atau sangsi hukum kepada pihak-pihak yang melakukan penyerobotan atau perampasan atas tanah adat tersebut.

\section{Kesimpulan}

Memperhatikan hasil penelitian yang telah dipaparkan secara mendalam pada bagian terdahulu, maka dapat disimpulkan bahwa Implementasi nilai-nilai Pancasila sila ke 5 dalam penerapan pembelaan hak kepemilikan atas tanah adat di Desa Sukajadi Kecamatan Cibaliung Kabupaten Pandeglang yang dikuasakan ke Lembaga Bantuan Hukum (LBH\& HAM) Sunan Gunung Jati Indonesia belum maksimal sebagaimana yang diharapkan oleh Pemberi Kuasa agar tanah yang telah dikuasai oleh Pemerintahan Kabupaten Pandeglang dikembalikan kepada ahli warisnya. Kendala yang dihadapi ada beberapa faktor antara lain kurang maskimalnya pelayanan pemerintahan desa setempat dalam memberikan data dan dokumen terkait tanah tersebut, Pemerintahan Kabupaten Pandeglang yang dalam hal ini adalah Bupati juga tidak memberikan jawaban atau tanggapan atas permasalahan tanah tersebut, termasuk Dewan Perwakilan Rakyat Daerah Kabupaten Pandeglang yang semestinya sebagai wakil rakyat harus pekah terhadap permasalahan rakyatnya dan tentunya memanggil Bupati Pandeglang untuk didengar dalam rapat komisi, sama sekali tidak jelas. 
Disinilah sangat dibutuhkan kehadiran negara dalam melaksanakan dan mewujudkan amanat Sila ke 5 Pancasila "Keadilan Sosial Bagi seluruh rakyat Indonesia" Suatu keniscayaan keadilan dapat ditegakkan tanpa adanya dukungan pemerintah. 
Mustamid

\section{BIBLIOGRAFI}

Arikunto, S. (2010). Prosedur penelitian. Jakarta: rineka cipta.

Lexy, J. M. (2002). Metode penelitian kualitatif. Bandung: Rosda Karya.

Nomor, U.-U. R. I. (16AD). tahun 2011 tentang Bantuan Hukum. Lembaran Negara Republik Indonesia Nomor, 104.

Simarmata, P. (2017). Hukum Zona Ekonomi Eksklusif dan Hak Indonesia Menurut Undang-Undang RI Nomor 5 Tahun 1983. Syntax Literate; Jurnal Ilmiah Indonesia, 2(2), 108-123. 